\title{
Catastrophic Failure of the Planet
}

\author{
Chip Fletcher
}

In 2013, when the carbon dioxide content of the atmosphere passed 400 parts per million ( $\mathrm{ppm}$ ) for the first time in fifty-five years of measurement-and probably more than 3 million years of Earth history-a TV political drama marked the event by staging an interview on the evening news with an EPA scientist. The anchor asked the scientist about how dangerous 400 ppm would be for humanity. "If you were the doctor and we were the patient, what's your prognosis - a thousand years, two thousand years?" The scientist's answer stops everyone in the newsroom in their tracks.

"The person has already been born who will die due to catastrophic failure of the planet."

Wow. I was stunned-not by the content, but that somebody in Hollywood was actually paying attention to the reality of climate change. "Yea, that's about right, and it's already started," I thought. The scientist described what this would look like: "mass migrations, food and water shortages, spread of deadly disease, endless wildfires - way too many to keep under control, storms that have the power to level cities ...."

With that warmup, let's consider climate change, based on peer-reviewed scientific literature. ${ }^{1}$ And let's not sugar-coat it.

In 2015, the United Nations passed the Paris Agreement to keep the rise of global temperatures "well-below $2^{\circ} \mathrm{C}\left(3.6^{\circ} \mathrm{F}\right)$ " above preindustrial levels, and to "pursue efforts" to stay within $1.5^{\circ} \mathrm{C}\left(2.7^{\circ} \mathrm{F}\right)$. But as the UN Environment Programme and others have repeatedly noted, there is a yawning gap between countries' actions and what is required to meet the Paris targets.

The release of carbon dioxide and other greenhouse gases is causing the climate to change 170 times faster than natural forces, and even after declarations of a global warming emergency, and twenty-six years of efforts by world governments, the scientific community, and citizens groups, average temperatures and fossil fuel emissions are still rising. Renewable energy use has risen and costs have fallen, but at far too slow a rate to offset the growth in fossil fuel consumption. Coal remains the single largest source of power generation, accounting for $36 \%$ of global power, while renewable energy provides only $10 \%$ of global power. In fact, the top fossil fuel producing nations are on track, and have announced plans to produce, about $50 \%$ more fossil fuels by 2030 than is compatible with stopping warming at $2^{\circ} \mathrm{C}$. 
Carbon dioxide emissions increased about $0.6 \%$ in 2019 , driven by a $5 \%$ increase in land-use emissions, including fire deforestation - the fastest rate in five years. While land use represented around $14 \%$ of total emissions, it contributed more than half of the 2019 increase.

Economic indicators and trends in global natural gas and oil use suggest that emissions will continue to rise over the next three decades. Concentrations of carbon dioxide in the atmosphere will increase. The 410 parts per million average in 2019 was $47 \%$ above preindustrial levels, a concentration not seen since the Pliocene Epoch, 2.6 to 5.3 million years ago. Global warming has increased air temperature by $1.2^{\circ} \mathrm{C}\left(2^{\circ} \mathrm{F}\right)$, a rate that has more than doubled in the past forty years. However, land regions have seen nearly $1.8^{\circ} \mathrm{C}$ warming, and the oceans only $0.8^{\circ} \mathrm{C}$.

The likely global temperature increase this century will be a median $3.2^{\circ} \mathrm{C}$ $\left(5.8^{\circ} \mathrm{F}\right)$. There is only a $5 \%$ chance that it will be less than $2^{\circ} \mathrm{C}$, and only $1 \%$ less than $1.5^{\circ} \mathrm{C}$. The year 2019 was the second warmest in recorded history; the fiveyear period 2015-2019 has been the hottest on record; and 2010 to 2019 was the hottest decade lived through by any man, woman, or child ... ever. Climate change risk is much greater than what the media usually portrays. The current release of carbon dioxide is affecting us ten times faster than any climate change event of the previous 66 million years. That's when an asteroid killed the dinosaurs.

Intolerable heat, extreme weather, animal and plant extinctions, and wildfires are all on the rise. Glaciers are melting, the oceans are warmer, and sea level is rising. Globally, a $12 \%$ increase in extreme rainfall is matched by a $10 \%$ increase in land area under drought. Due to current emissions, $70 \%$ of the world's population and gross domestic product face a $500 \%$ increase in flood impact. In the US, the number of weather disasters is up 14\% since 1995-2004, doubling since the previous decade. In 2019, there were fourteen weather and climate disaster events-three floods, eight severe storms, two tropical cyclones, and a wildfire, with losses exceeding \$1 billion for each. The 1980-2019 annual average is 6.5 events; but between 2015 and 2019, it was 13.8. Scientists have assessed more than 355 extreme weather events ranging from Hurricane Katrina to Russia's 2010 heatwave. Results indicate that human-caused climate change made $78 \%$ of them more likely or severe. Heatwaves account for $47 \%$, droughts $15 \%$, and heavy rainfall or floods for $15 \%$. The evidence is mounting that human activity is raising the risk of extreme weather, and especially weather linked to heat.

Thanks to today's levels of carbon dioxide in the air, staples such as rice, wheat, maize, and soy have as much as $13 \%$ less protein, zinc, vitamin B complex, and iron. By 2050, an additional 300 million people will be malnourished, and 1.4 billion women and children will have iron deficiency. Let's look at wheat. Today it provides $20 \%$ of all protein for humans. By 2050, the world's nine billion people will increase wheat demand by $60 \%$. But given anticipated droughts, floods, and higher $\mathrm{CO}_{2}$, actual wheat yield is projected to decline by $15 \%$ - a recipe for food shortages, desperation, and violent conflict. 
As for our freshwater crisis, $66 \%$ of all humans face water shortages at least one month each year. Seventeen nations are under extremely high water stress, meaning that every year, they are using almost all the water they have. Freshwater withdrawals are already exceeding sources. US withdrawals exceed natural recharge by $17 \%$, China by $22 \%$, India by $52 \%$, and North Africa and the Middle East by more than $1000 \%$ each year. By 2030, global water requirements are expected to exceed sustainable water supplies by $40 \%$. If warming continues at this rate, water supply deficits could increase five-fold, with once-in-a-hundred years droughts occurring every two to five years for most of Africa, Australia, southern Europe, southern and central US, Central America, the Caribbean, northwest China, and parts of South America.

With $1.2^{\circ} \mathrm{C}\left(2^{\circ} \mathrm{F}\right)$ global warming today, nearly one-third of the world's population is exposed to deadly heat waves. For every $1^{\circ} \mathrm{C}\left(1.8^{\circ} \mathrm{F}\right)$ increase, one billion people will have to adapt or migrate to stay within the climate conditions best suited for crops, livestock, and a sustainable outdoor work environment. As unlivable climate conditions spread, the already massive human migration problem will get much worse.

In the summer of 2019, two European heat waves just weeks apart shattered hundreds of all-time records-both linked to human-caused climate change. The one in late June 2019 reached $115^{\circ} \mathrm{F}$ in France, eclipsing its all-time record by more than $3^{\circ} \mathrm{F}$. A World Weather Attribution study concluded that its core was around $7^{\circ} \mathrm{F}$ warmer than it would have been a century ago, and that heat waves of this magnitude are ten times more likely now. The heat wave in late July reached all-time record highs in the UK, Belgium, the Netherlands, Germany, and Luxembourg. Paris reached nearly $109^{\circ} \mathrm{F}$, breaking the former record by $4^{\circ} \mathrm{F}$. Researchers determined that such a heat wave was ten to one hundred times more likely to occur now than before the Industrial Revolution. When it built north into the Arctic, that same heat wave caused the biggest melt day of the Greenland Ice Sheet in measured history.

In 2016, a quarter of the planet's ocean surface had its longest or most intense heat wave on record. In two regions - the Bering Sea of Alaska and waters off northern Australia - such an event was up to fifty times more likely due to humancaused climate change. The abnormally hot water triggered the worst mass coral-bleaching event on record for the Great Barrier Reef.

Unless warming is reduced, researchers estimate climate change could cause the extinction of more than one-third to one-half of all animal and plant species in only fifty years. The key variable driving these losses is maximum annual temperature - the hottest daily highs in summer. Extinctions will be two to four times more common in the tropics than in temperate regions-a big problem, since most plants and animals live in the tropics.

Although emissions have only warmed the surface $1.2^{\circ} \mathrm{C}$, the impacts are severe and widespread, because they magnify the stress that communities already 
place on natural systems. Across $65 \%$ of the terrestrial surface, land use and related pressures have led biotic intactness to decline beyond 10\%, a "safe" planetary boundary, with changes most pronounced in biodiversity hotspots. One recent paper concluded "the unparalleled appropriation of nature is causing the fabric of life on which humanity depends to fray and unravel” (Díaz et al.).

When the anchor in our TV scene asked the EPA scientist if this was the administration's official position, the scientist answered, “There isn't a position on this any more than there is a position on the temperature at which water boils." To those paying attention, it's been clear for years that climate change threatens the stability of civilization and the security of human communities. We are in the first stages of catastrophic planetary failure.

\section{Note}

1. See Xu et al.; Hofste et al.; Jones et al.; and Abatzoglou and Williams.

\section{Works Cited}

Abatzoglou, John T., and A. Park Williams. "Impact of anthropogenic climate change on wildfire across western US forests." PNAS, vol. 113, no. 42, 2016, pp. 11770-75.

Díaz, Sandra, et al. "Pervasive human-driven decline of life on Earth points to the need for transformative change." Science, vol. 366, no. 6471, 2019, p. eaax3100.

Hofste, Rutger Willem, et al. "17 Countries, Home to One-Quarter of the World's Population, Face Extremely High Water Stress.” World Resources Institute, 6 Aug. 2019, https://www.wri.org/blog/2019/08/17-countries-home-one-quarterworld-population-face-extremely-high-water-stress.

Jones, Kate E., et al. “Global trends in emerging infectious diseases.” Nature, vol. 451, 2008, pp. 990-93.

World Weather Attribution. "Human contribution to the record-breaking July 2019 heatwave in Western Europe.” 2 Aug. 2019, https://www.worldweatherattribution. org/human-contribution-to-the-record-breaking-july-2019-heat-wave-inwestern-europe/.

Xu, Chi, et al. "Future of the human climate niche." PNAS, vol. 117, no. 21, 2020, pp. $11350-55$.

Chip Fletcher is Associate Dean of Academic Affairs and a Professor in the School of Ocean and Earth Science and Technology, University of Hawai'i at Mānoa. 